\title{
Why Changing Minds is Difficult: An Introduction to a Living Systems View of Learning
}

\author{
Tim Goodwin* \\ Associate Professor of Education, Bemidji State University, United States
}

Submission: January 19, 2021; Published: March 09, 2021

*Corresponding author: Tim Goodwin, Associate Professor of Education, Bemidji State University, Bemidji Minnesota, United States

Keywords: Thinking; Ecosystem; Living system; Human brain; Knowledge; Schema; Brain neurology; Cognitive disequilibrium; Human mind.

\section{Opinion}

In this essay I am going to bring together Firtjof Capra's and Pier Luigi Luisi's living systems theory, Jonathan Haidt's moral foundations theory, and constructivist learning theory to think about why shifting one's thinking is difficult and do so in order to introduce the concept of a living systems view of learning. Let's begin with basic understanding of a living system as "autopoietic," meaning it "is a system capable of sustaining itself due to a network of reactions which continuously regenerate the components-and this from within the boundary 'of its own making'” ([1] pp.134). Living systems maintain itself and regenerate internally all its own components using resources from its surrounding environment. I'll start with a cell, but eventually expand this model to consider one's worldview as a living system as well.

Living systems are self-bound and nested in expanding layers of larger living systems. For example, a cell is bound by a membrane, but interacts with other cells to form and organize into tissues, creating systems of tissues organized into an organ, organized into organ systems, all of which are interlocked in feedback mechanisms to maintain the whole of the body's living system. The body, embedded in an ecosystem, takes in molecules and energy to self-maintain and regenerate (autopoiesis) and then returns waste in the form of molecules and heat energy to the larger ecosystem. It is the understanding of these feedback mechanisms helping the system maintain homeostatic stability that I am most interested in understanding and expanding on as a conceptual model for how one learns about, interprets, and ultimately makes meaning of their world-the essence of constructivist learning theory.
Using a graphic adapted from Capra \& Luisi [1] (pp.134), I illustrate, step-by-step, an autopoietic living cell embedded in its environment.

$$
\begin{aligned}
& \text { i. The cell is a } \\
& \text { ii. self-contained living system which is in } \\
& \text { iii. a larger ecosystem that gets. } \\
& \text { iv. inputs from that ecosystem. Those inputs determine. } \\
& \text { v. how the metabolic processes in the cell react. In so doing, } \\
& \text { vi. it produces needed molecular components, used to } \\
& \text { vii. } \quad \text { self-make and regulate as a bounded system. It then }
\end{aligned}
$$
expels waste product and heat.

viii. back into the ecosystem (Figure 1).

The cell maintains internal homeostasis through negative feedback loops. That internal homeostasis is continuously out of equilibrium as equilibrium would be a static, unchanging state without any exchange of energy, molecules, or information-so for a living system, death. Maintaining this constant, balanced state out of equilibrium, requires a regular input of energy and molecules from the environment. Therefore, a living system must constantly cycle matter and energy through itself to fuel its own autopoietic functions (being alive). Therefore, a living system is never at rest. It might be easier to understand using a simpler non-living system analogy. Consider the thermostat regulating the temperature of a house. What we as the inhabitants of the 
house deem comfortable might very well be far different than the conditions that would exist if no energy were used to heat or cool the house and the system was allowed to settle into a "natural" state of equilibrium-so temperature same inside as outside of the house. However, to keep our homes a constant comfortable temperature (a state of homeostasis), we set the thermostat at 72 degrees and the heating system employs a negative feedback loop to keep the house at 72 degrees. In the winter, when the temperature drops below that set point, the furnace engages until it reaches that set point. The warmed air once reaching 72 degrees detected by the thermostat then shuts down the very system that was creating the warm air-self regulation. This is a classic example of a negative feedback loop. The house is using energy and molecules from outside the system to maintain the preferred homeostatic state within the boundary of the system.

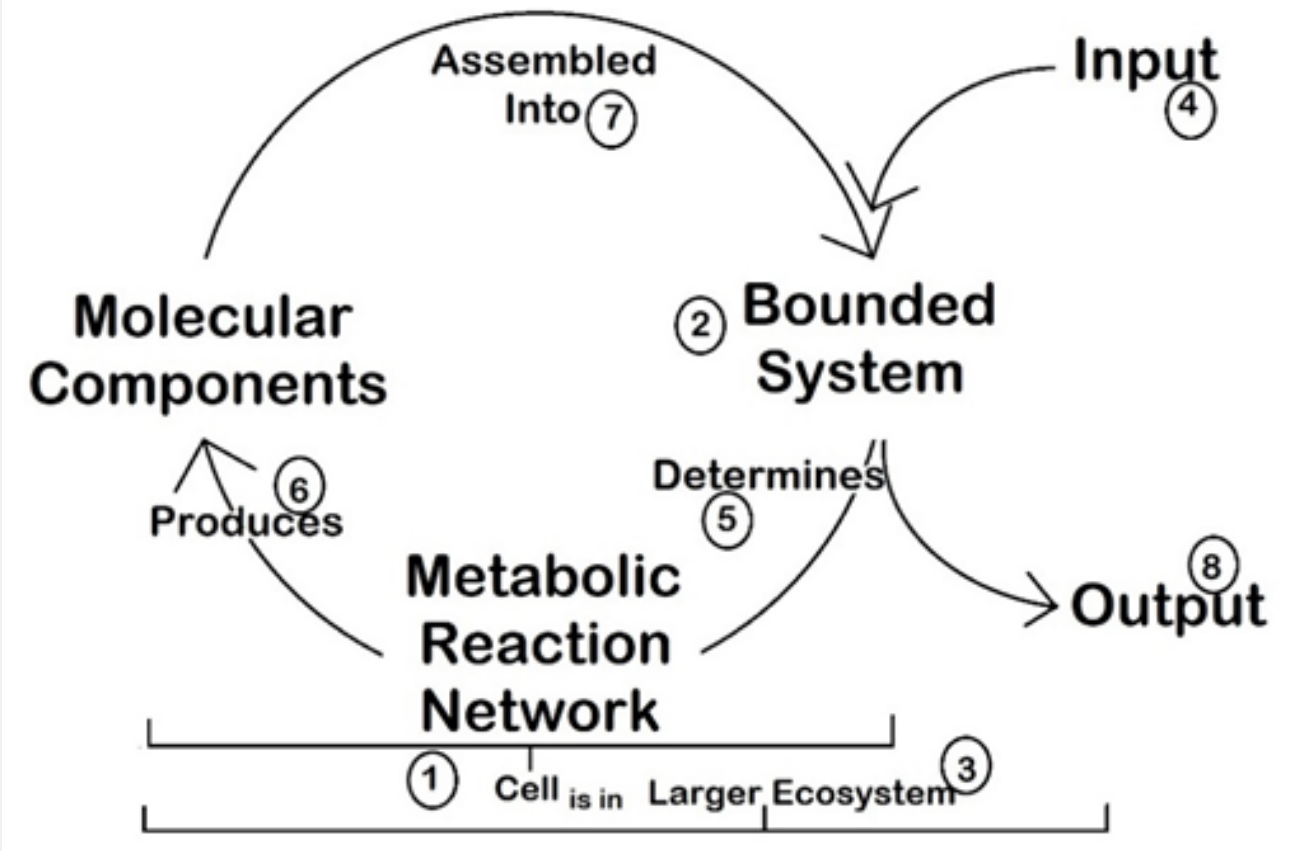

Figure 1: Building New Worldview.

Now, I want to expand this thinking beyond explaining how a living system (a human made of cells in this case) is interlocked with its physical world, to how one understands and makes sense of their world. I will use the same living systems theory model used to understanding life to understand the "life" of one's evolving (or static) worldview-their aggregate understanding of the world around them and how the human brain constructs this collection of understandings. A living thing itself is a set of complex systems nested together within a larger ecosystem/environment. The human brain is a system (made of smaller systems of cells) nested in the larger system of the human body. Therefore, the complex nature of how it works, meaning how it takes in, makes sense of, stores, and then recalls new knowledge, must also be understood through the lens of systems theory.

The collection of a person's knowledge and experience is an interlocked network of specific packets of information and memories each being what I am calling a "schema." As a photon is a packet of light energy, a chromosome is a packet of genetic information, a schema is a packet of information/experience. These are stored in an interlocked set of neural networks, which are stored in the human brain, which is yet another system nested inside the human body system, nested inside the ecological and social systems in which that body resides. So, let's return to the model I previously used and apply this system thinking to how we humans make sense of the world in which we live and construct our worldview (Figure 2).

i. The individual makes sense of the world as best they can with the information and experiences they've had, creating their "worldview." However, everyone's worldview is invariably incomplete, flawed, or of limited scope. Though flawed, they are at equilibrium, which is a comfortable "resting" state for any system, requiring no energy use. Remember, that a living system uses resources from its environment to exist at a stable state (homeostasis) far from equilibrium. 


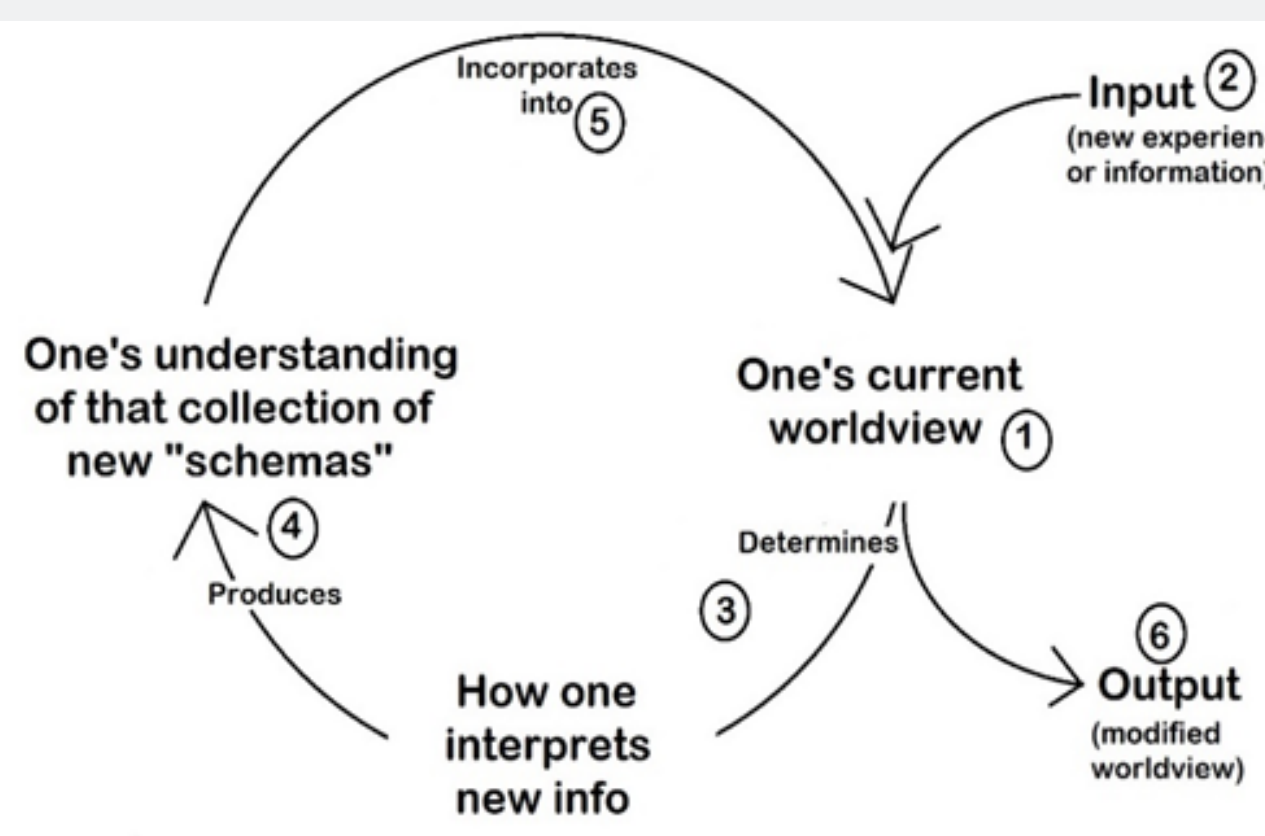

Figure 2: Living Systems.

ii. New information is put into the system. These could be spontaneous experiences or planned lessons from a formal teacher, or even self-selected information by the learner. You can probably see the danger there. I'm using the term "learner" to describe anyone exposed to new information, ideas, or experiences. So, anyone interacting with their world.

iii. The learner takes in that information and works with it. The degree to which they work with it, as opposed to watching someone else work with it, will determine both their ultimate depth of understanding and the longevity of that understanding. Will they just rent the information, or will they "own" it?

iv. Using prior knowledge and experiences as a foundation, they begin to make sense of this new experience or this piece of information (schema). If they have what I call a "lived" experience or authentic experience with it, they are more likely to attach it to an existing memory, which increases likelihood of building a long-lasting understanding. If it is completely new, they will construct a new metaphor to permanently house that information or experience, which will then become the foundation for new memories. You can begin to see that our knowledge (memories) is the aggregate of these schema stored in a complex system of our brain neurology as a series of interlocked systems themselves.

v. Now comes the most important part-embracing "cognitive disequilibrium," as Piaget labeled it. This new schema will have an impact on one's worldview, causing the learner to experience disequilibrium as the new schema will upset the previously existing the system of his or her "resting" worldview.
This is often uncomfortable. Recall that for living, growing, evolving lifeforms, a state away from equilibrium, but utilizing outside resources to maintain and fuel that stable state, is actually the homeostatic state for a living thing.

vi. At this point, we can fully embrace and embed the new schema and lean into our cognitive disequilibrium enough to own it and use it to push us to a new or modified worldview-where we will "rest" until a new schema is input into the system of our worldview and brain.

A person's worldview (all they know and how they make sense of it in the context of their life) is an extremely complex set of interlocked systems nested in complex interlocked systems. The more you can visualize the complexity of these interlocked systems, the easier it is to understand why changing them is difficult as they are all interconnected. All systems "prefer" to stay at a stable, unchanging state and only shift to a new state of equilibrium with the input and use of significant energy. Systems don't "like" to change-be they human mind/body systems, mechanical systems, or social systems. This includes what we know and how we learn. The concept of learning and the learner as being "Tabula rasa" is incorrect. Human's are not a blank slate. Or, to use a more modern metaphor, a blank hard drive to simply be filled up with new information. Everything that is taken in by the learner is filtered through, and eventually connected to the interlocked network of existing schema in the human brain. This impacts how the learner understands that new experience or information and what one does with that new schema. The individual begins with existing ideas, information, metaphors, and so on, and then takes in new 
information and experiences. They can take it in as presented and adjust their worldview, modify it to fit their pre-existing worldview, or simply dismiss it. Like a healthy living system, a healthy living worldview is one then that has the capacity to use (not energy) but schema to maintain a state of homeostasis far from equilibrium. Reconciling this disequilibrium that results in an expansion of knowledge engaging the whole self to make sense of content within a meaningful context-the understanding of self in the world [2]. So, why are these paradigm shifts so difficult? The following diagrams ([3], p. 41) show learning as paradigm shifts as the result of negative and positive feedback loops (Figure 3).
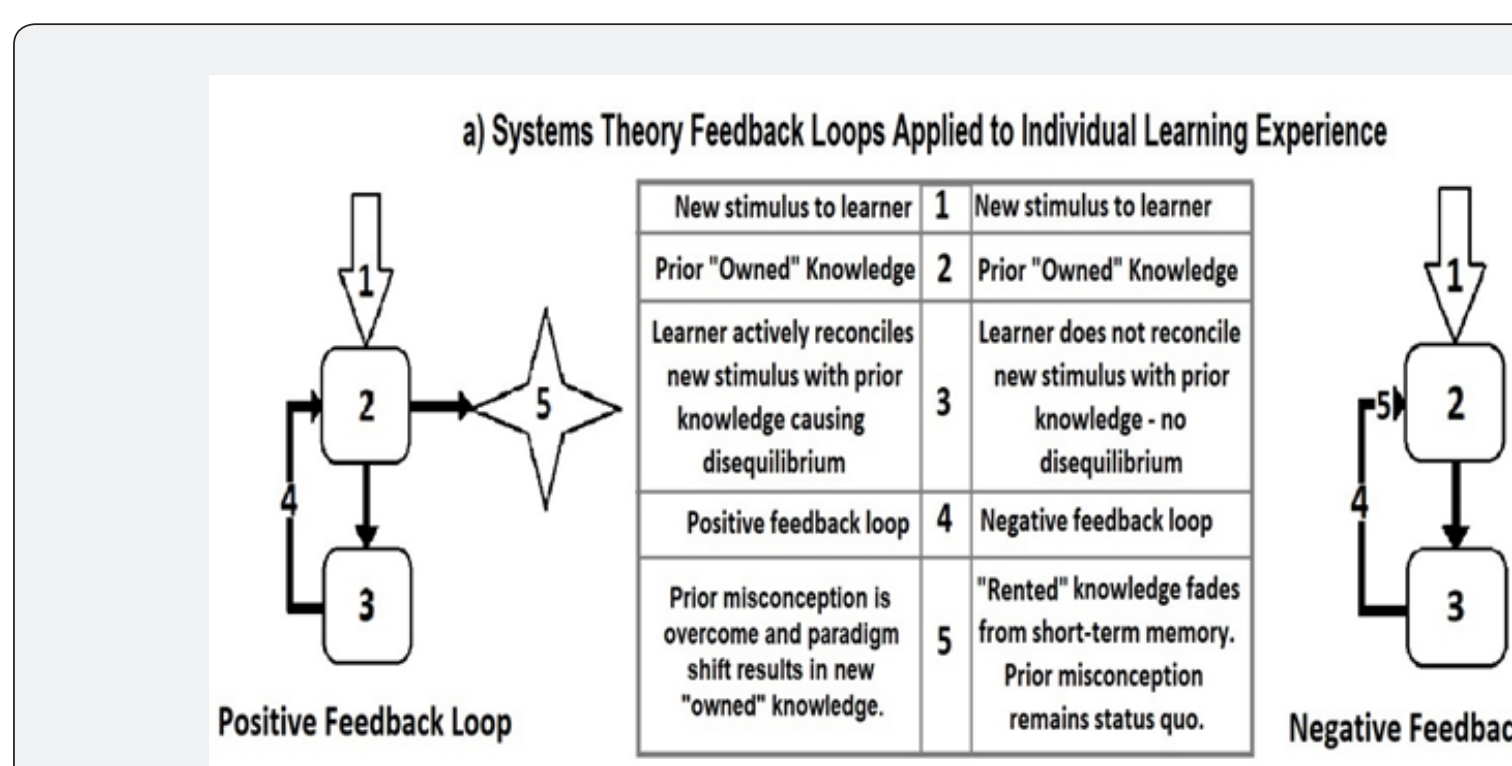

Negative Feedback Loop

\section{b) Systems Theory Feedback Loops Applied to Learning Resulting in Paradigm Shift}
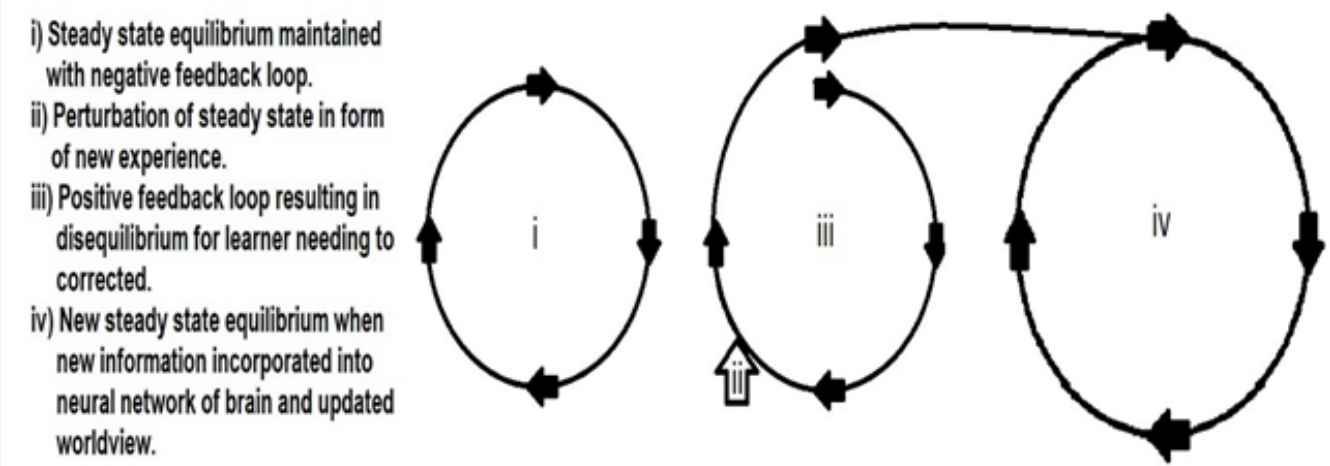

Figure 3: Learning Feedback Loop.

The story of how the human brain receives, stores, catalogs, and then recalls and makes sense of new information (so changes its mind) is a story of two brains: The lower, or unconscious, and upper, or conscious. Information enters the lower brain and immediately the thalamus makes a judgment of validity of the input. Is it worth paying attention to considering the current situation of the mind/body? If yes, then it goes to the amygdala and hippocampus to determine if it fits in an emotional or factual context. At this point, however, if the learner is in an emotional state of distress, the amygdala short-circuits the rest of the pathway, limiting your ability to form long-term memories with that particular schema and instead puts you into fight, flight, or freeze mode. The lower brain has a much longer evolutionary history than the upper brain, so its first fight, flee, or freeze in hopes of surviving, and only then analyze and learn from it. I think it is safe to say, that a significant portion of our population are currently living in a state of extreme emotional distress. Here's a flow chart mapping out the pathway of that "schema" ([3] p. 25) (Figure 4). 


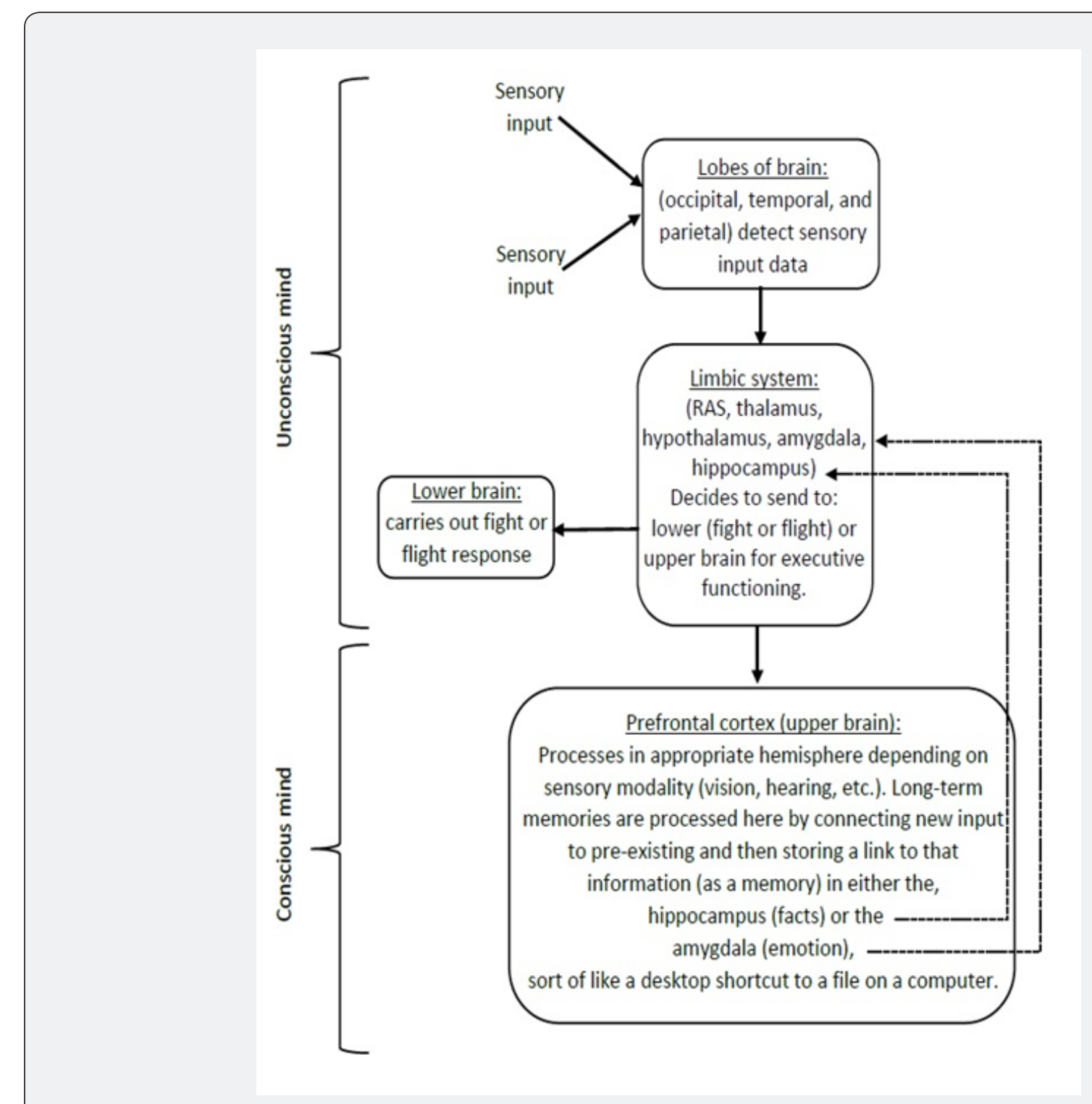

Figure 4: Pathway of learning in human brain.

I like to think of the process of forming new or changed memories with this metaphor. Imagine mold and mildew has appeared on the ceiling above a shower. If you simply paint over that spot with new white paint, within a couple of weeks the mold and mildew will grow back through the new paint. When you learn something new, if you do not purposefully and properly correct previous misconceptions and place that new schema into the right context of your evolving worldview, the new will eventually fade away and be forgotten. The prior knowledge will simply come back and retake its place in your long-term memory. When you repaint a bathroom, you must use primer that adequately kills the pre-existing mold and mildew. In learning we must reconcile what we already knew with what the new lived experience is and purposefully kill off the old misconceptions.
To understand why the emotional memories and context so often override new "factual" information, I'll use another metaphor Jonathan Haidt [4] uses in his book, The Righteous Mind: Why Good People are Divided by Politics and Religion. He likens the operation and decision-making process of the human mind as like an elephant and a rider. The rider is the controlled processes-the analytical or upper brain. The elephant is the autonomic processes-the lower brain. You can already see which beast is really in control of this situation.

Now, imagine you are leading a group of tourists riding elephants (but please do not ever do this) and one of the elephants and rider continue to go down a different path. The reality is that when riding an elephant, no matter what the rider wants or thinks it should do, a stubborn elephant who has made up its mind will 
choose the path to follow. So as the rider, or the leader of this voyage, you must appeal to the elephant first. You must provide subtle nudges and incentives for the elephant to choose the path you want, or simply change the pathway itself so the elephant wants to choose the desired path (for the rider). The rider is simply not strong enough to just make the elephant do what it is told. Often, the facts (the rider) cannot override the emotions (the elephant).

Such as it is with a person's established worldview. Appealing to the rider is progressively less and less effective the more agitated and stressed the elephant. I think that many of us are riding around on angry elephants. The more we yell at each other's elephants, the more obstinate they become, until it is all just indecipherable noise further agitating the elephant. Eventually, our elephant/ rider combination arrives at decisions about the economy, the pandemic, foreign policy, immigration, a candidate, etc., that others simply cannot understand how we would ever make such a choice. The synthesis of living systems views and learning theory might allow us to move beyond behaviorist models of motivation and didactic instruction in education, and continual fact-bombing of political opponents and others with whom we disagree in order to facilitate evolving and expanding worldviews. From developing curriculum to having civil discussion about politics, we must consider and realize that the human brain, and the paradigms one has constructed, are complex systems requiring nurturing of ideas, opportunities to have lived experiences to consider new information and perspectives and are greatly impacted by one's emotions and prior experiences. Just telling someone how it is does not ever work to educate someone or change their mind and perspective. In fact, it might result in just the opposite-a hardening of a static worldview.

\section{References}

1. Capra, Fritjof, Pier Luigi Luisi (2014) The systems view of life: A unifying vision. Cambridge University Press. United Kingdom.

2. Caine RN, Geoffrey Caine (1994) Making connections: Teaching and the human brain. Menlo Park California. Addison-Wesley, United States.

3. Goodwin Tim (2020) Consider, Construct, Confirm: A New Framework for Teaching and Learning. Kendall Hunt. Dubuque, IA, United States.

4. Haidt, Jonathan (2012) The Righteous Mind: Why Good People are Divided by Politics and Religion. First Vintage Books. New York, United States.

\section{Your next submission with Juniper Publishers} will reach you the below assets

- Quality Editorial service

- Swift Peer Review

- Reprints availability

- E-prints Service

- Manuscript Podcast for convenient understanding

- Global attainment for your research

- Manuscript accessibility in different formats

( Pdf, E-pub, Full Text, Audio)

- Unceasing customer service

Track the below URL for one-step submission https://juniperpublishers.com/online-submission.php 